\title{
WORKSHOP ECO-BATIK BERBASIS KONSERVASI LOCAL WISDOM BAGI GURU- GURU PAUD/TK DI KOTA JAMBI SEBAGAI UPAYA REVITALISASI BUDAYA BATIK JAMBI
}

\author{
Nyimas Muazzomi ${ }^{1}$, Indryani ${ }^{2}$, Nova Susanti $^{3}$, Aulia Sanova $^{4}$ \\ ${ }_{1,2,3,4}$ Universitas Jambi \\ Corresponding Author Email: nova_fisikaunja@unja.ac.id
}

(Artikel Masuk: 15 November 2020; Artikel Diterima: 24 Desember 2020; Artikel Terbit: 26 Desember 2020)

\begin{abstract}
Batik is one of Indonesia's ancestral cultural heritages that must be preserved because it has the character of cultural elements based on local wisdom which is full of social and spiritual values of an area. In ancient times, batik processing techniques were still very traditional, using painting motifs and natural dyes. One of the ways to preserve the existence of batik so that it is not eroded by the modernization era is through educational media by introducing and socializing batik to the golden generation from an early age, so it is necessary to revive the activity of teaching batik culture. This can be started by providing a form of training and mentoring for PAUD teachers in Jambi City. Achievement of soft skills from the results of this activity is the creation of a participant's creativity in painting and blending batik colors, bringing up life skills in the art of batik, awareness of caring and loving the environment, adding to the experience of environmental insight (social experience) and of course creating it. a work created by the participants in the form of batik products that are environmentally friendly because they use natural dyes. Meanwhile, the long-term achievements are in the form of journal publications and printed teaching materials for modules on Eco-Batik. The resulting product is written batik with flora and fauna motifs according to the characteristic theme of environmentally friendly kindergarten / early childhood children (EcoBatik). In the coloring process using natural dyes derived from the extract of jengkol skin, dragon fruit, inay leaves, suji leaves and turmeric. Likewise in the process of color locking (fixation), so that the color of the fabric looks old then added gambier powder, lime water and tunjung.
\end{abstract}

Kata Kunci: Eco-batik, Local Wisdom, Guru PAUD/TK

\begin{abstract}
Abstrak
Batik merupakan salah satu warisan budaya leluhur Indonesia yang harus dipertahankan karena memiliki karakter unsur budaya berbasis local wisdom yang sarat akan nilai-nilai sosial dan spiritual suatu daerah. Pada dahulu kala teknik pengerjaan batik masih bersifat sangat tradisional dengan menggunakan motif lukis dan pewarna alam. Salah satu cara menjaga kelestarian keeksistensian batik agar tidak punah tergerus oleh zaman modernisasi adalah dengan melalui media pendidikan dengan cara memperkenalkan dan memasyarakatkan batik kepada generasi emas sejak dini, sehingga perlu dihidupkan kembali kegiatan membelajarkan budaya membatik. Hal ini bisa diawali dengan dengan memberikan sebentuk pelatihan dan pendampingan bagi guru-guru PAUD yang ada di Kota Jambi. Capaian soft skill dari hasil kegaitan ini adalah terciptanya suatu kreativitas peserta dalam melukis dan memadukan warna batik, memunculkan kecakapan hidup (life skill) dalam seni perbatikan, sikap kesadaran peduli dan cinta lingkungan, menambah pengalaman yang berwawasan lingkungan (social experience) dan tentunya tercipta nya sebuah karya hasil karya para peserta berupa produk batik yang ramah lingkungan karena menggunakan pewarna alam. Sementara untuk capaian jangka panjang berupa publikasi jurnal dan bahan ajar cetak modul tentang Eco-Batik. Karya produk yang dihasilkan berupa batik tulis dengan motif flora dan fauna sesuai tema karakteristik anak TK/PAUD yang ramah lingkungan (Eco-Batik). Pada proses pewarnaannya menggunakan pewarna alam yang berasal dari ekstrak kulit jengkol, buah naga, daun inay, daun suji dan kunyit. Begitu juga pada proses penguncian warna (fiksasi), agar warna kain terlihat tua maka ditambahkan serbuk gambir, air kapur dan tunjung.
\end{abstract}

Kata Kunci: Eco-batik, Local Wisdom, Guru PAUD/TK 


\section{A. PENDAHULUAN}

Eksistensi pemakaian batik saat ini telah berkembang secara dinamis baik dari kalangan pemakai, motif, warna dan gaya. Pada masa lalu unsur pemilihan motif yang dikenakan dilihat berdasarkan keturunan, jabatan dan kesempatan dalam menjalankan ritual-ritual tertentu. Saat ini penggunaan batik tidak lagi identik untuk acara yang sifatnya tradisional dan kebudayaan, namun sudah menjadi salah satu trend gaya fashion yang tidak memandang usia dan dapat di gunakan baik untuk untuk acara yang sifatnya formal atau informal. Batik merupakan salah satu identitas keberagaman budaya masyarakat Indonesia sejak abad ke-7 dan ini direfleksikan dari sejumlah warna, corak dan keragaman motif yang dihasilkan memiliki ciri khas, makna filosofi serta fungsi yang bervariasi dari masing-masing daerah. Simbol ekspresi kreativitas dan spiritual rakyat Indonesia ini, maka pada 2 Oktober 2009 Badan PBB UNESCO mengakui batik sebagai warisan dunia dan ditetapkan sebagai hari batik nasional.

Batik berasal dari kata ambatik yang berasal dari bahasa Jawa, amba dan tik yang artinya menulis titik. Jadi batik mengacu kepada teknik seni melukis titik-titik, dengan kata lain batik adalah karya melukis corak gambar diatas kain. Untuk menghasilkan macam-macam rupa motif dan sifat khusus dari batik, maka dalam pembuatannya batik dapat digambar pada mori dengan menggunakan alat khusus yang bernama canting (Salma, 2013). Sementara Standar Nasional Indonesia (SNI) No. 08-0239 1989, batik sebagai bahan tekstil menggunakan lilin batik (malam) yang berfungsi untuk membuat pola gambar dan dapat juga digunakan sebagai zat perintang agar pada saat pencelupan warna tidak larut pada kain.

Proses pembuatan batik tidak lepas dari proses pewarnaan sebagai unsur memperindah dan mempercantik karya batik. Penggunaan pewarna kain batik dapat dikategorikan menjadi dua yaitu zat pewarna alam yang dapat diperoleh dari bermacam-macam tumbuhan, dengan memanfaatkan bagian buah, akar, daun, bunga, biji atau kulit pohon (Amalia \& Akhtamimi, 2016) dan pewarna buatan yang disintesis secara kimiawi turunan hidrokarbom aromatik seperti benzena, toluena, naftalen dan antrasena. Contoh zat pewarna sintetik yang umumnya digunakan dalam industri batik adalah naftol, indigosol, remasol, rapide, ergan, soga dan idanthrene (Atirza \& Soewondo, 2018).

Dahulu kala, pada umumnya pewarna batik dibuat masih dengan cara tradisional dengan memanfaatkan bahan-bahan alam dan alat-alat sederhana berbeda dengan kondisi saat ini yang banyak beralih menggunakan alat yang lebih modern dan menggunakan pewarna 
batik buatan yang dampaknya secara akumulatif sangat merugikan bagi kesehatan maupun lingkungan karena sifatnya yang karsinogen dan membahayakan. Limbah cair sisa pewarnaan jika di buang ke badan lingkungan seperti tanah maupun air akan menyebabkan matinya mikroorganisme dan biota-biota yang hidup, terjadinya pencemaran, hilangnya unsur hara sehingga tanah menjadi tidak subur, memicu kanker, gangguan fungsi hati, penyakit kulit dan hiperaktif pada anak yang disebab kan dari air minum yang masuk kedalam tubuh.

Saat ini penggunaan zat warna sintetik cenderung diminati dan sering digunakan dalam pembuatan batik karena akan lebih mudah diperoleh di pasaran, ketersediaan warna terjamin, jenis warna bermacammacam, dan lebih praktis dalam penggunaannya. Untuk membuat batik dengan pewarna alami membutuhkan proses yang panjang. Kain direndam dalam rebusan tanaman selama berhari-hari dan berulangulang. Berbeda dengan pewarna buatan yang prosesnya jauh lebih cepat. Untuk menghasilkan nuansa warna yang lebih natural pada pewarnaan batik alam, maka membutuhkan proses berulang untuk mendapatkan warna yang jelas dan pekat sehingga pengerjaannya lebih rumit dan membutuhkan waktu yang cukup lama.

Pewarna sintetis digolongkan berbahaya dan beracun karena pada pembuatannya asam sulfat atau asam nitrat di reaksikan logam berat seperti arsen. Berbeda dengan zat pewarna alami batik yang berasal dari bahanbahan organik alam yang mengandung klorofil, karetonoid, curcumin, antosianin yang sifatnya mudah terdekomposisi atau terurai sehingga ramah lingkungan dan tidak menimbulkan efek penyakit. Melihat dampak kedepan akibat penggunaan pewarna sintesis yang secara tidak langsung dapat mengancam kelangsungan hidup dan lingkungan, maka saat nya perlu dilakukan sebuah upaya untuk

Hal ini disebut dengan Eco-batik dan ini juga sejalan dengan program pemerintah mengembangkan konsep go green untuk membangun kepedulian lingkungan hidup berkelanjutan dalam menjaga Kota Jambi yang bersih dan sehat. Tradisi budaya membatik mengandung unsur-unsur pembelajaran yang mengeksplor akar-akar kebudayaan dengan mengembangkan unsur kearifan lokal yang sarat akan nilai-nilai moral dan spriritual seperti kesucian, ketegasan, amanah, keindahan, kasih sayang, tanggung jawab, bekerjasama, kuat, konaah dan rasa syukur. Makna nilai filosofi ini terkadung pada gambaran setiap motif yang dihasilkan dari batik sehingga mencerminkan sifat atau karakter yang disesuaikan dengan ciri khas kehidupan masyarakat dan icon Kota Jambi.

Salah satu cara menjaga kelestarian keeksistensian batik agar tidak punah tergerus 
oleh zaman modernisasi adalah dengan melalui media pendidikan di tingkat sekolah, dengan cara memperkenalkan dan memasyarakatkan batik kepada generasi emas sejak dini, sehingga perlu dihidupkan kembali kegiatan membelajarkan budaya membatik. Hal ini bisa diawali dengan dengan memberikan sebentuk pelatihan dan pendampingan bagi guru-guru PAUD yang ada di Kota Jambi dengan harapan kedepannya dapat menjadi mediator transfer knowladge yag baik dalam menyalurkan ilmunya memberikan pelajaran membatik kepada anak-anak usia dini guna melatih kemampuan motorik halus anak.

Pendidikan konservasi local wisdom dalam membatik perlu diedukasi sejak dini dengan memperkenalkan motif-motif sederhana bertema flora, fauna dan pesona alam yang disesuaikan dengan icon dan budaya lokal ciri khas daerah Jambi. Pemanfaatan pewarna alami dalam dalam kegiatan membatik juga dapat mengangkat nilai-nilai budaya menuju jejaring global menumbuhkan kecintaan terhadap pengetahuan asli masyarakat sebagai bagian dari budaya bangsa yang berimplikasi terhadap konservasi sumber daya alam sekitar serta keseimbangan lingkungan. Upaya ini juga dilakukan agar anak-anak sejak dini mengetahui jika dearah Jambi memiliki potensi kekayaan alam dan kearifan lokal yang perlu dijaga. Oleh karenanya lembaga pendidikan juga diharapkan mampu berperan aktif dalam upaya meningkatkan konservasi lingkungan dan pelestarian batik melalui pembelajaran berbasis budaya lokal.

Provinsi Jambi dikenal dengan daerah sentra batiknya yang mampu menghasilkan keragaman corak dan motif sesuai dengan kultur masyarakat dari lingkungan disekitar Jambi yang terinspirasi dari tanaman maupun hewan, seperti motif Angso Duo, Kaca Piring, Bungo Teratai, Bungo Melati, Durian Pecah, Kupu,-kupu, Tampuk Manggis, Kembang Duren, Bungo Tanjung, dan lain sebagainya. Untuk teknik pewarnaan dapat memanfaatkan potensi sumber bahan alam yang ada di sekitar daerah Jambi seperti daun suci/daun pandan, buah naga, daun indigo (tarum), buah manggis, kayu sepang, dan lain sebagainya.

Pengembangan strategi membatik berbasis produksi bersih ramah lingkungan dan konservasi cirikhas budaya lokal derah Jambi melalui program Eco-batik perlu disosialisasikan dan dibelajarkan kembali karena merupakan salah satu bentuk usaha preventif pengelolaan lingkungan untuk menjaga kelestarian alam melalui budidaya penanaman tanaman yang hampir langka dan upaya mempertahankan identitas kekayaan corak dan motif batik Jambi guna menggenerasikan nilai budaya warisan nenek moyang ditengah pestnya arus digitalisasi medern. 
Pada pelatihan membatik ini, guru-guru PAUD diberi ruang kebebasan berkreasi menggambar batik dengan motif flora, fauna, atau icon daerah Jambi. Pada proses membatik, guru-guru tidak menggunakan lilin panas pada umumnya karena sangat membahayakan, namun menggunakan pasta tepung sebagai penggantinya dan teknik pewarnaan colet yang menggunakan hasil ekstrak tanaman atau buah-buah lokal daerah Jambi.

Batik pertama kali masuk ke daerah Jambi pada tahun 1875 yang dieprkenalkan oleh Haji Muhibat seorang pendatang dari daerah Jawa Tengah yang menetap di Jambi, kala itu penggunaan dan perdagangan batik masih sangat terbatas karena tidak semua kalangan dapat menggunakan batik. Corak yang dihasilkan hanya ukiran rumah adat Jambi dan dalam pembuatannya masih sangat tradisional menggunakan pewarna batik alam. Batik tulis Jambi memiliki ciri khas yang unik dan eksotis. Sesuai dengan perkembangan zamannya, kini dapat dihasilkan beragam motif namun tetap mengedepankan karakter khas Jambi yang khas dengan tampilan warnawarna cerah.

Pada masa tahun 1970-an, batik Jambi sempat menghilang karena ada larangan beraktivitas namun pada tahun 1980 batik Jambi kembali diproduksi. Seiring dengan kemajuan teknologi, tingkat kebutuhan dan harga produksi para pengrajin beralih menggunakan zat warna sintetis dan batik cetak menggunakan cap, akibatnya budaya pelestarian batik tulis dengan menggunakan bahan alam, semakin lama semakin terkikis.

Saat ini penggunaan zat warna alam tidak begitu populer dan familiar baik di kalangan masyarakat maupun para pengrajin batik nusantara di Kota Jambi, hal ini sebabkan karena prosesnya dinilai jauh lebih rumit, setiap tahapan membutuhkan proses dan bahan baku alam yang susah didapat sementara pewarna sintetis karena lebih praktis tinggal di beli ditoko.

Untuk mempertahankan eksistensi batik yang natural dan ramah lingkungan perlu di perkenalkan dan diajarkan sejak dini melalui jenjang Pendidikan Anak Usia Dini (PAUD) melalui pembelajaran seni dan keterampilan. Selain mempertahanan batik sebagai warisan ethnik budaya bangsa Indonesia, kegiatan membatik dapat melatih stimulus motorik halus anak karena sangat berpengaruh terhadap kreatvitas, mengontrol variasi gerakan-gerakan yang sulit dan membatu perkembangan otak dan kecerdasan.

Berdasarkan observasi dan wawancara dengan dua orang guru PAUD Di Kota Jambi, menyatakan jika keterampilan motorik halus anak masih banyak yang rendah, diamana anak belum mampu membuat garis lengkung dan miring, mengkoordinasikan mata dan tangan, serta. Salah satu metode yang dapat digunakan dalam meningkatkan kemampuan 
motorik halus anak usia dini adalah dengan seni kriya membatik yang didalamnya terdapat unsur mewarna, menggambar dan mencolet. Pembelajaran batik disekolah merupakan pendidikan seni dan nilai dalam konteks kebangsaan yang erat kaitannya dengan pengembangan karakter dan watak suatu bangsa. Guru sebagai agen mediator dan fasilitator yang dianggap mampu dan kompeten dalam bidangnya perlu dibekali pengetahuan membatik, mengingat guru-guru di TK Melati 2 dan TK Putri Balqis masih banyak yang belum memiliki latar belakang pendidikan seni rupa sehingga dalam mentransfer pembelajaran seni membatik masih dirasa sangat kurang. Maka kegiatan pelatihan PPM membatik ini dirasa sangat perlu dilakukan dengan harapan dapat membudayakan warisan batik leluhur dan menerapkan pelajaran membatik bagi anakanak sesuai usia baik di PAUD maupun di kelompok TK.

\section{B. PELAKSANAAN DAN METODE}

Sejak batik ditetapkan sebagai warisan leluhur bangsa Indonesia tak benda pada tanggal 02 Oktober 2010 oleh UNESCO, maka keberadaan batik perlu dijaga eksistensinya agar tidak diakui oleh negara lain. Setiap daerah yang ada di Indonesia memiliki batik yang memiliki ciri khas, karakter, motif dan juga mengandung makna filosofi yang dalam. Keberadaan batik Jambi sudah cukup terkenal dikancah nasional maupun internasional dengan inspirasi motif keragaman flora, fauna dan icon daerah Jambi. Dahulu kala pewarnaan batik masih menggunakan bahan-bahan alam yang didapat dari potensi sumber daya alam daerah Jambi yang kesediaannya sangat melimpah, namun semakin hari penggunaannya sudah bergeser ke pewarna sintetis akibat pengerjaannya yang sangat rumit dan proses yang panjang dan sumber alam yang semakin langka sehingga susah ditemukan.

Mengingat daerah Jambi memiliki keragaman batik yang khas, maka keberadaan Eco-Batik (batik dengan pewarna alam) dengan mempertahankan motif yang berciri budaya lokal perlu tetap di lestarikan dan terus diperkenalkan agar tidak tergerus oleh perubahan zaman. Upaya konservasi batik dapat diperkenalkan melalui media pendidikan pengajaran dan produksi batik yang dapat dimulai sejak dini di tingkat PAUD maupun di TK. Maka perlu kiranya para guru-guru PAUD maupun TK di bekali keterampilan membatik yang mana nantinya diharapkan dapat memberi pengalaman yang sama ke anak-anak PAUD maupun TK.

Hasil dari kegiatan pelatihan ketrampilan kerajinan ini diharapkan nantinya dapat turut menjaga kelestarian motif batik Jambi yang khas dengan warna-warna natural yang berasal dari potensi alam daerah Jambi sehingga ini juga menjadi umpan balik 
sebagai upaya pelestarian tanamatanaman khas Jambi yang keberadaannya semakin langka dan turut menciptakan keseimbangan lingkungan yang ramah, bersih dan harmonis.

Kegiatan diawali dengan proses persiapan, pemberian materi tentang pemahaman akibat pemakaian warna sintetik, pelatihan praktek dan pendampingan, monitoring dan evaluasi serta pelaporan kegiatan. Program pelatihan yang di selenggarakan berupa pengenalan teori dan diskusi-informasi (10\%), praktek dan demonstrasi (80\%) dan evaluasi hasil (10\%). Selain memberikan pelatihan, kegiatan ini di upayakan dalam bentuk pendampingan agar proses pembelajaran yang telah di peroleh, dapat di implementasikan secara tepat dalam mengedukasi lanjutan kepada anak-anak PAUD maupun TK

Metode yang diterapkan dalam kegiatan pelatihan adalah sistim pembelajaran metode ceramah, diskusi-informasi/tanya jawab, demonstrasi dan percobaan langsung. Pola pelatihan dilakukan secara berkala, yang diawali dengan pemberian materi, proses pembuatan ekstrak pewarna alam, menentukan corak, tema dan motif khas yang melambangkan unsur karakteristik masyarakat Jambi, membatik, pencelupan dengan menggunakan pewarna alam kemudian di akhir sesi peserta mempresentasikan hasil eksplorasi pengembangan kreativitas batik dan unsur-unsur nilai budaya dari tema motif yang di pilih sebagai bentuk kompetisi penilaian.

Dengan metode ini diharapkan dapat meningkatkan motivasi dan apresiasi peserta terhadap pemanfaatan zat warna dari bahan alam hasil komoditi daerah untuk pengembangan produksi tekstil kerajinan batik dan menjaga warisan leluhur yang mengandung nilai kearifan lokal, sehingga dapat membawa kebaikan dan kesejahteraan serta kebahagiaan bagi si pemakai.

$$
\text { Evaluasi pelaksanaan kegiatan }
$$
pengabdian ini akan dilakukan pada saat proses maupun diakhir kegiatan pengabdian sebagai bentuk pertanggungjawaban kegiatan baik kepada masyarakat, stakeholder maupun instansi yang mencakup evaluasi analisis kebutuhan dan potensi. Uutuk evaluasi proses, tim pengabdi berupaya kontribusi untuk pemahaman ilmiah tentang hasil suatu program dengan menilai pelaksanaan aktivitas program melalui pelatihan, pendampingan dan evaluasi hasil kompetensi. Sedangkan pada akhir proses kegiatan, evaluasi mencakup efektifitas dan efisiensi program serta evaluasi dampak dengan menilai kepuasan sasaran.

\section{HASIL DAN PEMBAHASAN}

Akulturasi dan revitalisasi guna menjaga asset cultur heritage melalui kegiatan membatik pada kegiatan Pegabdian Kepada Masyarakat ini berlangsung dengan lancar dan aman. Program kegiatan yang telah dilakukan 
adalah berupa serangakaian workshop yang dilaksanakan dalam bentuk berupa pelatihan, pebekalan, pengajaran, praktek dan pendampingan dalam proses pembuatan batik dengan menggunakan pewarna alami sebagai subtitusi pewarna kimia. Kegiatan ini bertujuan untuk menjaga eksistensi batik tulis menggunakan pewarna alami tetap terjaga di tengah kondisi zaman yang sudah banyak terseret arus globalilasi dan kemuktahiran teknologi disamping itu juga melatih kreativitas, sikap peduli terhadap lingkungan mengingat efek bahaya yang ditimbulkan dari pewarna sintetis serta dapat menumbuhkan sikap berwirausaha bagi masyarakat sebagai usaha peningkatan perekonomian keluarga dan masyarakat tentunya mengingat nilai jual yang sangat tinggi dan dapat di ekspor hinga ke manca negara.

$\begin{array}{cll}\text { Sebelum } & \text { kegiatan } & \text { Pengabdian } \\ \text { dilakukan, tim } & \text { personalia } & \text { Pengabdian }\end{array}$
bekoordinasi terlebih dahulu dengan mitra terkait dengan perencanaan, waktu dan tempat serta mekanisme teknis proses kegiatan yang akan dilaksanakan. Pelaksanaan kegitan di laksanakan pada hari Sabtu tanggal 25 Juli 2020 yang diadakan di aula dan halaman terbuka LKP Putri Nayu dengan diikuti oleh 10 orang peserta dari target sasaran sebanyak 15 orang dikarenakan karena program dilaksanakan di tengah-tengah masa pandemi. Peserta kegitan yang hadir berasal kelompok masyarakat sekitar, guru PAUD/TK dan mahasiswa calon guru PGPAUD Universitas Jambi. Rangkaian susunan proses kegiatan pelatihan yang telah di lakukan adalah di awali dengan kegiatan pembukaan berupa kata sambutan dari pihak sekolah di lanjuti dengan ucapan terimakasih dari tim pengabdian kepada pihak sekolah dan para peserta atas kerjasama dan partisipasinya untuk melakukan kegiatan pelatihan dan di tutup dengan doa dan ramah tamah.

Muara dari kegiatan ini adalah sebentuk pelatihan membatik menggunakan bahan pewarna alami. Namun sebelum praktek para peserta diberi pebekalan materi pengantar tentang keragaman khasanah batik tulis Jambi yang perlu dilestarikan dan mengenalkan bahan-bahan alam apa saja yang dapat digunakan sebagai pewarna batik yang tentunya bersifat ramah lingkungan, mudah diperoleh dan pastinya aman. Pemanfaatan sumber-sumber bahan alam sebagai proses pewarnaan batik sejalan dengan konsep penggunaan produk yang ramah lingkungan (Alamsyah, 2018). Maka kegiatan ini sesuai jika di implementasikaan untuk diajarkan oleh anak-anak PAUD/ TK sebagai sentra belajar seni dan melukis dengan menggunakan media kain selain media kertas sebagai upaya pelestarian warisan leluhur melalui sebuah karya seni dan edukasi dengan corak ragam daerah Jambi yang dipadukan dengan warna yang serasi, soft, cerah dan colour full yang 
sesuai dengan karakter anak PAUD/TK yang ceria.

Pewarna batik yang digunakan dalam kegiatan ini adalah tanaman khas hasil komoditi alam propinsi Jambi dengan memanfatkan bagian tanaman seperti daun, buah, bunga, batang, kulit buah, umbi dan sebagainya. Agar menghasilkan sari pewarna yang kental dan pekat, maka perlu di ekstrak dengan teknik panas perebusan dan pengendapan ampas (Muthi'ah \& Evvyani, 2019). Agar menghasilkan warna yang lekat dan tidak memudar maka ditambah kapur dan gambir kedalam larutan sari warna alam. Bagian tanaman yang di gunakan sebagai penghasil warna pada pembuatan batik pada kegiatan ini adalah kulit buah jengkol yang mengahasilkan perpaduan warna ungu, pink dan coklat, eksrak kunyit yang bewarna kuning, daun inay bewarna orange, daun suji menghasilkan warna hijau dan buah naga dengan khas merah mudanya. Ekstrak warna dasar yang dihasilkan dari bahan alam tersebut dapat juga dikombinasi menjadi perpaduan dua bahan atau lebih sehingga menghasilkan warna baru seperti perpaduan ekstrak daun suci dan buah naga yang menghasilkan warna merah cerah. Teknik penggabungan dan perpaduan warna juga diajarkan dalam teknik membatik pada kegiatan ini.

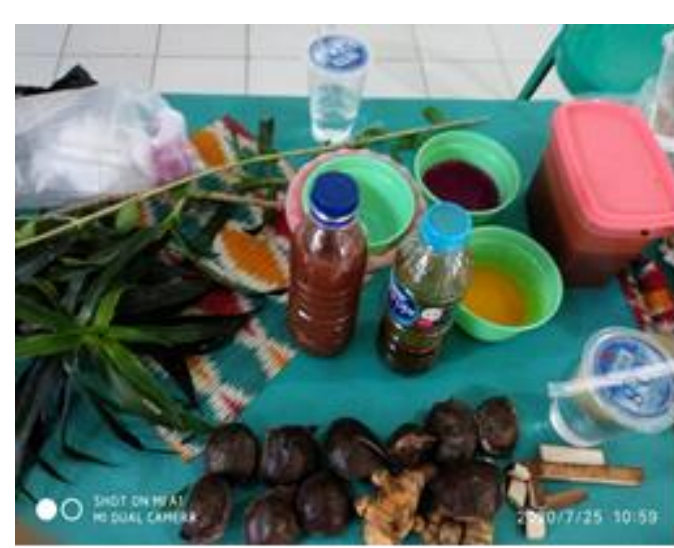

Gambar 1. Berbagai Jenis Tanaman Penghasil

Warna Alam

Teknis kegiatan inti selanjutnya adalah praktek membatik. Langkah awal adalah para peserta diajarkan teknik melukis gambar pada kain mori menggunakan pensil kemudian melekatkan malam/lilin sesuai dengan garis pola gambar yang sudah dibuat dan memberikan ornamen-ornamen berupa pola baik berupa garis, lingkaran atau lengkung dengan menggunakan canting.

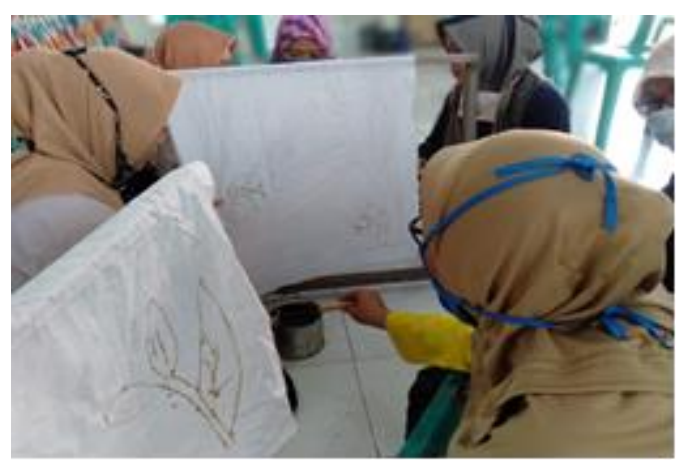

Gambar 2. Menorehkan Lilin Pada Pinggiran Motif

Setelah kering dilanjukan dengan colet yaitu memasukkan warna pada bagian gambar dengan menggunakan kuas atau kapas. Kemudian kain diangin-anginkan tanpa terkena sinar matahari hingga benar-benar kering dan memberi pengulangan proses 
pewarnaan sebanyak tiga kali agar mengahasilkan warna yang lekat, cerah dan tidak mudah luntur pada saat pencelupan.

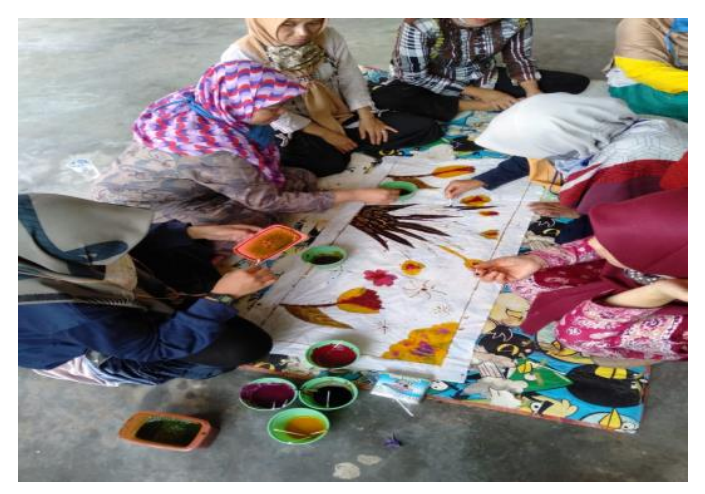

Gambar 3. Proses Pemberian Warna Dengan

Metode Colet

Proses selanjutnya adalah nembok, dimana menutup bagian latar pola motif untuk memberikan ruang sehingga menghasilkan warna baru pada pewarnaan yang kedua cukup dengan menggunakan kapas dan kemudian di angin-anginkan sampai kering, kemudian dilakukan pencelupan. Tahap penting lainnya sekaligus tahap akhir adalah proses fiksasi yaitu pengikatan atau penguncian warna agar warna bertahan lebih lama, tahan terhadap gosokan dan tidak mudah pudar (Dwi Anzani et al., 2016). Dalam prosesnya kain direndam kedalam larutan ekstrak tunjung selama 10-15 menit yang bertujuan penguncian warna agar menghasilkan warna yang kuat dan terlihat lebih tua. Warna akhir pada kain belum sepenuhnya terlihat secara jelas, untuk memunculkannya makan kain melalui proses "nglorod" terlebih dahulu yaitu proses perebusan untuk membersihkan sisa-sisa lilin yang masih menempel dengan menambahkan soda abu. Tahap akhir dari pembatikan ini adalah penjemuran dan pengeringan kembali dan kain batik pun siap untuk digunakan.

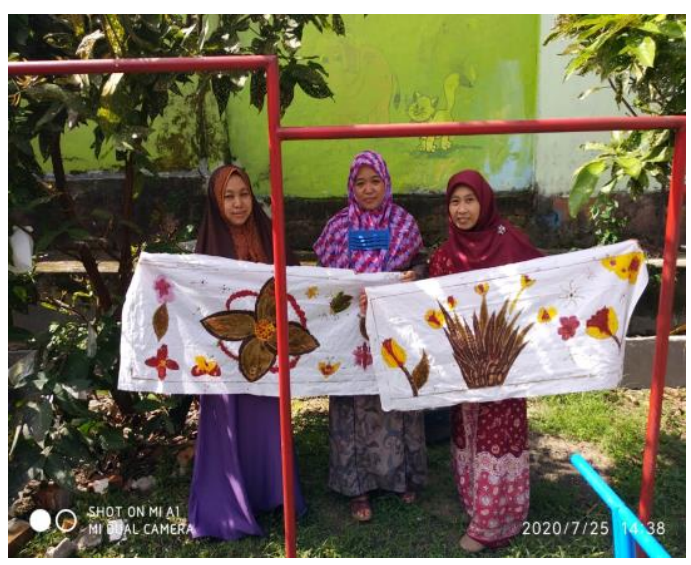

Gambar 4. Produk Eco-Batik Kreasi

Proses pembuatan batik tulis apalagi dengan menggunakan pewarna alam memang sangat rumit untuk dikerjakan karena memakan waktu yang cukup lama, mulai dari tahap mengekstrak pigmen bahan alam untuk mendapatkan sari warna, proses pewarnaan dan pencelupan yang memerlukan perlakuan yang berulang-ulang. Namun hal ini sesuai dengan produk yang dihasilkan memiliki karakteristik yang unik, ekslusif dan memiliki unsur karakter alami yang sangat kuat, dapat dijadikan komoditas produk unggulan lokal yang perlu dilestarikan serta memiliki potensi peluang pasar yang cukup tinggi (Pujilestari, 2017), maka karena itu memang perlu sekali produk lokal asli Indonesia batik tulis dari pewarna alam ini perlu dilestarikan dari generasi ke generasi agar tidak hilang akibat arus teknologi yang semakin canggih. 


\section{HASIL LUARAN}

Capaian soft skill dari hasil kegaitan ini adalah terciptanya suatu kreativitas peserta dalam melukis dan memadukan warna batik, memunculkan kecakapan hidup (life skill) dalam seni perbatikan, sikap kesadaran peduli dan cinta lingkungan, menambah pengalaman yang berwawasan lingkungan (social experience) dan tentunya tercipta nya sebuah karya hasil karya para peserta berupa produk batik yang ramah lingkungan karena menggunakan pewarna alam. Sementara untuk capaian jangka panjang berupa publikasi jurnal dan bahan ajar cetak modul tentang Eco-Batik.

Selama proses kegiatan, para peserta terlihat begitu antusias dan berusaha untuk terlibat secara aktif, cepat tanggap dalam merespon kegiatan, memiliki keingintahuan yang sangat besar, tidak sungkan untuk bertanya, memperhatikan setiap penjelasan yang diberikan, berani mencoba untuk berkreasi dan berinovasi dan mengikuti acara setiap sesinya sampai selesai.

Selama kurun waktu enam (6) bulan program pengabdian ini dilaksanakan dan kegiatan ini dapat berlangung dengan baik dan lancar berkat dukungan dari mitra selaku stakeholder maupun elemen kelompok masyarakat dalam hal ini guru-guru TK/PAUD sebagai peserta yang telah memberi kesempatan bagi tim Pengabdi untuk merealisasikan penyelenggaraan program workshop dan praktek pelatihan Eco-batik. Berkat kerjasama dan komunikasi yang intens, maka pada proses perencanaan, persiapan, pelaksanaan dan evaluasi proses kegiatan dapat berjalan dengan baik dan tepat waktu walaupun diselenggarakan di tengah-tengah wabah covid. Para peserta pun telah berkenan meluangkan waktunya dan terlihat begitu antusias dan sukarela dalam mengikuti kegiatan tiap sesinya mulai dari awal pembukaan, pemberian materi sampai kegiatan inti yaitu membuat eco-batik yang memerlukan waktu yang panjang dan sedikit rumit. Pihak mitra pun sangat responsif menyambut positif kegiatan ini serta berperan aktif, bersedia meluangkan waktu dan memberi kontribusi penyediaan sarana prasarana seperti listrik, air, peralatan dan ruang aula sebagai ruang kegiatan.

Dalam proses pembuatan batik menggunakan pewarna alam tentunya memerlukan waktu yang cukup lama mulai dari pembuatan ekstrak warna, melukis motif, memberi malam, pemberian warna, pencelupan, fiksasi sampai tahap terakhir yaitu membuang bekas-bekas lilin. Perlakuan ini membutuhkan pengulangan yang harus di lakukan secara kontinyu dan bertahap. Kegiatan membatik dirasa sangat mengasyikkan namun sebenarnya bukanlah pekerjaan yang gampang, perlu keahlian khusus terutama dalam teknik mencanting 
guna menorehkan lilin pada pinggiran outline motif. Jika terlalu banyak malam yang terisi kedalam perut canting maka lilin akan berhamburaan jatuh ke kain dan tidak tembus hingga kebelakang kain, maka perlu dilakukan latihan-latihan kecil dan pemberian contoh praktek oleh para peserta supaya mahir dalam teknik pemberian malam ini. Disamping itu masih terbatasnya jumlah ketersediaan alatalat membatik, seperti kompor dan canting yang jumlah nya tidak sesuai dengan banyaknya peserta. Namun hal ini dapat diatasi dengan pembagian tugas baik pada saat melukis, mencanting dan mewarnai.

\section{PENUTUP}

\section{Simpulan}

Berdasarkan dari hasil kegiatan pelaksanaan kegiatan pengabdian kepada masyarakat yang telah dilakukan, maka dapat di simpulkan: 1) Karya produk yang dihasilkan berupa batik yang ramah lingkungan (Eco-Batik) karena pada proses pewarnaannya menggunakan pewarna alam yang berasal dari ekstrak kulit jengkol, buah naga, daun inay, daun suji dan kunyit Begitu juga pada proses penguncian warna (fiksasi), agar warna kain terlihat tua maka ditambahkan serbuk gambir, air kapur dan tunjung. 2). Pelatihan ini menjadi sarana edukasi dan melatih para peserta khusus nya guru-guru TK/PAUD sebagai usaha untuk mengenalkan kembali pembuatan batik dengan pewarna alami yang menjadi kekhasan batik Indonesia, khususnya di daerah Jambi. 3). Meningkatnya life skill, kreatifitas, peduli lingkungan dan social experience masyarakat yang berwawasan lingkungan dengan memaknai batik sebagai warisan nenek moyang yang harus dijaga keeksistensiannya. 4). Para peserta telihat sangat antusias yang dapat dilihat dari rasa ingin tahu, memperhatikan penjelasan maeri, berusaha terlibat dan merasa tertarik untuk mencoba berkreasi dan berinovasi dan semangat dalam melakukan kegiatan tahap demi tahap. 5)

Kegiatan berlangsung lancar, tepat waktu dan sesuai dengan yang diharapkan.

\section{Saran}

Pelatihan teknik Eco-Batik ini dirasa sangat penting untuk melestarikan budaya Indonesia yang hampir punah, maka perlu di sarankan agar dilakukan pembinaan keterampilan membatik menggunakan bahan alam sebagai pewarna tidak sebayas hanya pada guru-guru TK/PAUD namun juga dapa di implementasikan ke sekolah-sekolah dasar, menengah atau sederajat sebagai mata pelajaran berbasis muatan lokal untuk mengangkat budaya Jambi agar tidak mudah ditengah arus globalisasi.

Mengingat keberadaan tanaman pewarna yang semakin hari semakin sulit ditemukan bahkan langka maka perlu usaha dari semua kalangan masyarakat untuk 
melakukan pelestarian budidaya dan konservasi sebagai program keberlajutan untuk mendukung aktivitas budaya membatik dan dapat meningkatkan iklim perekonomian masyarakat.

\section{Ucapan Terima Kasih}

Ucapan terima kami tim pengabdian ucapkan kepada Lembaga Penelitian Pengabdian Masyarakat (LPPM) Universitas Jambi yang telah mendukung penuh kegiatan pengabdian.

\section{E. DAFTAR PUSTAKA}

Alamsyah, A. (2018). Kerajinan Batik dan Pewarnaan Alami. Endogami: Jurnal Ilmiah Kajian Antropologi, 1(2), 136. https://doi.org/10.14710/endogami.1.2.136148

Amalia, R., \& Akhtamimi, I. (2016). Studi Pengaruh Jenis Dan Konsentrasi Zat Fiksasi Terhadap Kualitas Warna Kain Batik Dengan Pewarna Alam Limbah Kulit Buah Rambutan (Nephelium Lappaceum). Dinamika Kerajinan Dan Batik: Majalah Ilmiah, 33(2), 85. https://doi.org/10.22322/dkb.v33i2.1474

Atirza, V., \& Soewondo, P. (2018). Penyisihan Zat Warna Naphthol Pada Limbah Cair Batik Dengan Metode Adsorpsi Menggunakan Adsorben Tanah Liat Dan Regenerasinya. Jurnal Teknik Lingkungan, 24(April), 93-107.

Dwi Anzani, S., Wignyanto, W., Hindun Pulungan, M., \& Rosallina Lutfi, S. (2016). Pewarna Alami Daun Sirsak (Annona muricata L.) untuk Kain Mori Primissima (Kajian: Jenis dan Konsentrasi Fiksasi). Industria: Jurnal Teknologi Dan Manajemen Agroindustri, 5(3), 132-139. https://doi.org/10.21776/ub.industria.2016.0 05.03 .3

Muthi'ah, W., \& Evvyani, L. (2019). Eksplorasi Teknik Pewarnaan Alam Dengan Ekstrak Kayu Jambal Pada Batik Kayu Gempol. Jurnal Narada, 6 (September).

Pujilestari, T. (2017). Optimasi Pencelupan Kain Batik Katun Dengan Pewarna Alam Tingi (Ceriops Tagal) dan Indigofera Sp. Dinamika Kerajinan Dan Batik: Majalah Ilmiah, 34(1), 53. https://doi.org/10.22322/dkb.v34i1.2606

Salma, I. R. (2013). Corak Etnik dan Dinamika Batik Pekalongan. Dinamika Kerajinan dan Batik, 30(2), 85-97. https://doi.org/http://dx.doi.org/10.22322/d kb.v30i2 